\title{
Pengembangan Prototype Sistem Informasi Simpan Pinjam Koperasi Pribadi Manjung Ngawen Klaten
}

\author{
Maria Atik Sunarti Ekowati a,1,*, Endang Satyawati ${ }^{a, 2}$, Retno Palupi ${ }^{a, 3}$, SM Santi Winarsih ${ }^{\mathrm{a}, 4}$ \\ ${ }^{a}$ Universitas Kristen Surakarta, Jln. RW Monginsidi No. 36-38, Surakarta 57134, Indonesia \\ ${ }^{1}$ maria.atik@gmail.com *; ${ }^{2}$ endang.satyawati@uks.ac.id; ${ }^{3}$ rtnplp_2005@yahoo.com; ${ }^{4}$ kshervida@yahoo.co.id \\ * Koresponsendi penulis
}

ARTICLE INFO

Article history

Menerima 21 Februari 2021

Revisi 25 Juni 2021

Diterima 9 Juli 2021

Kata Kunci

Cooperative

Prototype

Information System

Transaction

\section{ABSTRACT}

The term cooperative comes from the foreign language co-operation. Cooperative means joint effort. A cooperative is a business unit that collects and distributes funds for members of the cooperative itself. One of the cooperative business units is a savings and loan cooperative. Each member of the Savings and Loans Cooperative must make savings in accordance with the cooperative's provisions. Members can make loans, managed transactions are member savings transactions and member loan transactions. Savings and loan cooperative funds come from cooperative members. Because this savings and loan really helps the needs of members, if this savings and loan facility is dissolved because there is no coordination in data processing on savings and loans, the people in ngawen, manjung, will be less viable for their livelihoods, so that many children drop out of school, the result will be to destroy the nation's development and the state, because of that, it is necessary to develop a Manjung Ngawen Cooperative UMKM Savings and Loan Information System. Development objectives help, facilitate and accelerate cooperative administration in managing transactions. The method used by WatterFall, the result of system development is that the system can help calculate loan interest, loan installments, remaining unpaid loans, share SHU for each member and display data on reports on deposits, loans, and member payments.

This is an open access article under the CC-BY-SA 4.0 license.

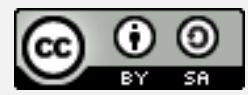

\section{Pendahuluan}

Seiring berkembangnya teknologi informasi dalam segala bidang yang sangat dirasakan manfaatnya oleh manusia, koperasi pun merasakan manfaat yang sama. Banyaknya proses bisnis yang terjadi didalam menjalankan sebuah koperasi menuntut efisiensi waktu dan cara kerja yang cepat dan tepat yang mana pada akhirnya meningkatkan mutu pelayanan kepada anggotanya. Koperasi adalah sebuah lembaga usaha sebagai sarana untuk mengembangkan dan membangun potensi serta menegakkan kemandirian pada suatu organisasi ataupun kelompok. Koperasi dibangun atas usaha bersama dalam sebuah kelompok berdasarkan asas demokrasi ekonomi dan kekeluargaan. Koperasi "PRIBADI" yang beralamatkan di Manjung, Ngawen, Klaten. Merupakan salah satu organisasi sebagai unit kesejahteraan anggota, dalam organisasi ini khususnya para warga masyarakat di lingkungan manjung, ngawen klaten dengan jumlah anggota yang tidak sedikit. Koperasi ini menangani pada sektor simpan pinjam, yaitu memberikan jasa simpan pinjam pada pengurus maupun anggota koperasi. Kondisi saat ini pengelolaan transaksi Manjung 
"PRIBADI" Ngawen, untuk simpanan, pinjaman maupun angsuran masih dilakukan secara manual. Proses transaksi seperti penghitungan angsuran pinjaman, penghitungan tabungan tiap anggota, dilakukan dan dicatat secara manual dan belum tertata rapi. Kondisi ini menimbulkan permasalahan yaitu menyebabkan timbulnya kesalahan penulisan dan pencatatan serta lamanya waktu pencarian data. Sistem komputerisasi adalah cara tepat untuk mengatasi permasalahan yang dihadapi koperasi pribadi manjung ngawen. Sebab itu dibuat sebuah sistem informasi perangkat lunak untuk menggantikan pekerjaan secara manual menjadi berbasis sistem informasi. Sistem informasi tersebut diharapkan dapat mempermudah dan dapat mengatur jalannya koperasi untuk kedepannya.

Pada penelitian ini penulis merujuk penelitian sebelumnya yang berhubungan dengan sistem simpan pinjam sebagai rujukan bagi penulis untuk dijadikan referensi. Sukadi (2013), dalam penelitiannya yang berjudul "Sistem Informasi Simpan Pinjam Pada Koperasi Wanita Putri Harapan desa Jatigunung Kecamatan Tulakan" menjelaskan bahwa bahasa pemrograman PHP sebagai sarana pembuatannya. Sistem inforrmasi ini menghasilkan halaman web yg diakses mengggunakan web browser. Dengan sistem ini pengolahan transaksi dan akuntansi pada koperasi wanita putri harapan menjadi lebih cepat dengan data akurat. Koperasi Pegawai Republik Indonesia Selamat Sejahtera (KPRIMATRA) memiliki jumlah anggota 735 orang pada akhir tahun 2014. Koperasi ini dikelola oleh Drs.Nasution sebagai ketua koperasi dan Nasutman, S.Pd., M.Si sebagai sekretaris di koperasi tersebut. Dengan jumlah anggota yang ada, pegawai koperasi masih melakukan transaksi simpan pinjam menggunakan sistem pencatatan manual dengan buku. Sistem pencatatan manual yang ada tidak dapat mendata anggota secara sistematis, terkadang membuat kesulitan pegawai koperasi dalam melacak data simpanan, data pinjaman, dan data angsuran pada transaksi simpan pinjam.

Saat ini ada beberapa masalah yang dihadapi oleh banyak koperasi dalam proses simpan pinjam yaitu masih menggunakan sistem kerja paperbase (sistem kerja dengan pemanfaatan kertas), pengelolaan data koperasi yang belum efektif dalam hal ini contohnya pengelolaan pendaftaran anggota Koperasi, pada proses pendaftaran anggota masih dengan cara mengisi formulir pendaftaran kemudian diajukan kembali secara langsung kepada koperasi. Pengelolaan data pada proses simpan pinjam dan pembuatan laporan keuangan masih mengalami kesulitan karena dalam pengelolaannya masih menggunakan Microsoft Excel sehingga pihak koperasi kesulitan dalam pengelolaan dan memperoleh informasi yang diinginkan. Sehingga koperasi membutuhkan aplikasi berbasis web untuk memudahkan interaksi antara anggota koperasi dengan pengurus koperasi. Berdasarkan latar belakang yang penulis uraikan diatas, maka penulis mengambil judul "Pengembangan Prototype Sistem Informasi Simpan Pinjam Koperasi Pribadi Manjung Ngawen Klaten". Diharapkan dengan adanya sistem informasi simpan pinjam dapat membantu dalam transaksi simpan pinjam pada koperasi tersebut.

\section{Metode / Algoritma yang Diusulkan}

\subsection{Jenis Penelitian}

Jenis penelitian ini termasuk penelitian eksperiment, menurut Maryati (2007:104), Penelitian eksperimen merupakan jenis penelitian yang memanipulasi atau mengontrol situasi alamiah menjadi situasi buatan (artificial) sesuai dengan tujuan penelitian. Adapun tujuan dari penelitian ini adalah : (1). Memberikan kemudahan dalam pengolahan data simpan pinjam. (2). Memudahkan pegawai koperasi untuk melihat informasi data simpanan, pinjaman dan angsuran setiap anggotanya. (3). Memudahkan pegawai koperasi untuk menginputkan data anggota, data simpanan, data pinjaman dan data angsuran. Ruang lingkup pembahasan masalah dalam penelitian ini penulis hanya membatasi permasalahan yang ada sebagai berikut : (1). Sistem berisi tentang pengelolaan data meliputi login setiap anggota, data anggota, data simpan, data pinjam dan data angsuran. (2). Laporan yang dihasilkan meliputi laporan simpanan, laporan pinjaman, laporan angsuran. (3). Sistem dibangun berbasis web dengan bahasa pemograman PHP dan database menggunakan MySql.

\subsection{Teknik dan Alat Pengembangan Sistem}

\subsubsection{Model Waterfall}


Dalam penelitian ini penulis menggunakan model pengembangan waterfall karena lebih simple dan mudah dimengerti oleh kaum awam. Menurut Rosa dan Shalahuddin (2013:28), model SDLC (software development life cycle) air terjun (waterfall) sering juga disebut model sekuensial linier (sequential linear) atau alur hidup klasik (classic life cycle). Model air terjun menyediakan pendekatan alur hidup perangkat lunak secara sekuensial atau terurut dimulai dari analisis, desain, pengodean, pengujian, dan tahap pendukung (support). Berikut adalah gambar model air terjun:

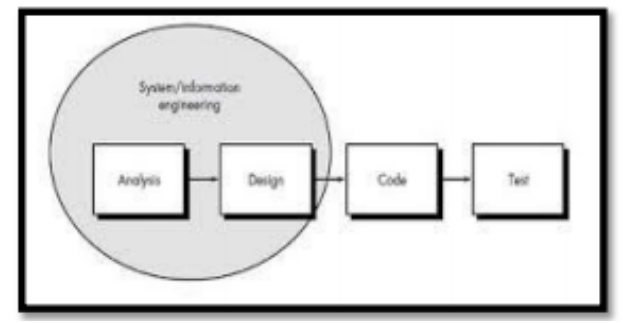

(Sumber: Rosa dan Shalahuddin (2013:29))

Fig. 1. Illustrasi Model Waterfall

Model Waterfall pada Fig. 1. ini memiliki tahapan sebagai berikut :

1. Analisis yaitu Proses pengumpulan data untuk kebutuhan dilakukan secara intensif untuk mespesifikasikan kebutuhan perangkat lunak agar dapat dipahami perangkat lunak seperti apa yang dibutuhkan oleh user.

2. Desain perangkat lunak yaitu proses multi langkah yang focus pada desain pembuatan program perangkat lunak termasuk struktur data, arsitektur perangkat lunak, representasi antarmuka, dan prosedur pengkodean. Tahap ini mentranslasi kebutuhan perangkat lunak dari tahap analisis kebutuhan ke representasi desain agar dapat diimplementasikan menjadi program pada tahap selanjutnya.

3. Pembuatan Kode Program (Koding) yaitu proses pembuatan kode program dengan desain harus ditranslasikan ke dalam program perangkat lunak. Hasil darai tahap ini adalah program komputer sesuai dengan desain yang telah dibuat pada tahap desain

4. Pengujian adalah proses pengujian koding dengan focus pada perangkat lunak secara dari segi lojik dan fugsional dan memastikan bahwa semua bagian sudah diuji. Hal ini dilakukan untuk meminimalisir kesalahan (error) dan memastikan keluaran yang dihasilkan sesuai dengan yang diinginkan.

5. Pemeliharaan adalah sebuah proses pengembangan sistem atau tidak menutup kemungkinan sebuah perangkat lunak mengalami perubahan ketika sudah dikirimkan ke user mengalami perubahan. Perubahan bisa terjadi karena adanya kesalahan yang muncul dan tidak terdeteksi saat pengujian. Tahap pemeliharaan dapat mengulangi proses pengembangan mulai dari analisis spesifikasi untuk perubahan perangkat lunak yang sudah ada, tapi tidak untuk membuat perangkat lunak yang baru.

\subsubsection{Alat dan Teknik Pengujian}

\subsubsection{Teknik Uji Coba Black Box}

Menurut Pressman (2002:551), Pengujian balck box berfokus pada persyaratan fungsional perangkat lunak. Dengan demikian, pengujian balck box memungkinkan perekayasa perangkat lunak mendapatkan serangkaian kondisi input yang sepenuhnya menggunakan semua persyaratan fungsional untuk suatu program. Pengujian black box bukan merupakan alternative dari teknik white box, tetapi merupakan pendekatan komplementer yang kemungkinan besar mampu mengungkap kelas kesalahan daripada metode white box.

\section{Metode Penelitian}

Sedangkan metode yang dipakai adalah metode prototype dengan Analisa berorientasi object. Pada penelitian yang dilakukan cara menganalisa dan merancang aplikasi menggunakan pemrograman berorientasi objek. Sedang pengembangan sistem menggunakan metode prototype. 
Prototype didefinisikan sebagai alat yang memberikan ide bagi pembuat maupun pemakai potensial tentang cara sistem berfungsi dalam bentuk lengkapnya, dan proses untuk menghasilkan sebuah prototype disebut prototyping.

\subsection{Analisa Berorientasi Obyek}

Analisis berorientasi obyek atau Object-Oriented Analisis (OOA) dimulai dengan menyatakan suatu masalah, analis membuat model situasi dari dunia nyata, menggambarkan sifat yang penting. Dalam menganalisa suatu sistem, analis harus bekerja dengan pihak yang membutuhkan sistem untuk memahami masalah tersebut dengan jelas.

UML ( Unfied Modelling Language ) adalah salah satu alat bantu yang sangat handal di dunia pengembangan sistem yang berorientasi obyek. Hal ini disebabkan karena UML menyediakan bahasa pemodelan visual yang memungkinkan bagi pengembang sistem untuk membuat cetak biru atas visi mereka dalam bentuk yang baku, mudah dimengerti serta dilengkapi dengan mekanisme yang efektif untuk berbagi ( sharing) dan mengkomunikasikan rancangan mereka dengan yang lain.

Metode Booch dari Grady Booch sangat terkenal dengan nama metode Design Object Oriented. Metode ini menjadikan proses analisis dan design ke dalam empat tahapan interatif, yaitu identifikasi kelas-kelas dan obyek-obyek, identifikasi semantik dari hubungan obyek dan kelas tersebut, perincian interface dan implementasi. Keunggulan metode Booch adalah pada detil dan kayanya dengan notasi dan elemen [1].

1) Activity Diagram Activity diagram menggambarkan proses bisnis dan urutan aktifitas dalam sebuah proses, yang mana dipakai pada business modelling untuk memperlihatkan urutan aktifitas proses bisnis karena bermanfaat untuk membantu memahami proses secara keseluruhan dalam memodelkan sebuah proses.

2) Use Case Diagram Use case diagram menggambarkan kebutuhan sistem dari sudut pandang user dan memfokuskan pada proses komputerisasi. Sebuah use case dapat menggambarkan hubungan antara use case dengan actor. Secara umum use case adalah pola perilaku sistem dan urutan transaksi yang berhubungan yang dilakukan oleh satu actor.

3) Class Diagram Class adalah sebuah spesifikasi yang jika diinstansiasi akan menghasilkan sebuah obyek dan merupakan inti dari pengembangan dan desain berorientasi obyek. Class menggambarkan keadaan (atribut/properti) suatu sistem, sekaligus menawarkan layanan untuk memanipulasi keadaan tersebut (metode/fungsi). Class diagram menggambarkan struktur dan deskripsi class, package dan obyek beserta hubungan satu sama lain seperti containment, pewarisan, asosiasi, dan lainlain. Class memiliki tiga area pokok, yaitu : Nama (dan stereotype), Atribut, dan Metode.

\subsection{Model Protype}

Metode Prototype merupakan suatu paradigma baru dalam metode pengembangan perangkat lunak dimana metode ini tidak hanya sekedar evolusi dalam dunia pengembangan perangkat lunak, tetapi juga merevolusi metode pengembangan perangkat lunak yang lama yaitu sistem sekuensial yang biasa dikenal dengan nama SDLC atau waterfall development model. [2]

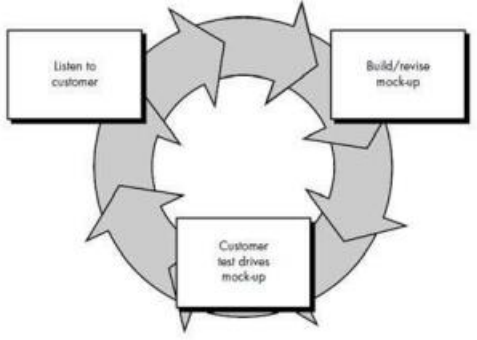

Fig.2. Model Prototype

Berikut adalah Tahapan - tahapan Proses Pengembangan dalam Model Prototype, yaitu : 
1) Pengumpulan kebutuhan Pelanggan dan pengembang bersama-sama mendefinisikan format seluruh perangkat lunak, mengidentifikasikan semua kebutuhan, dan garis besar sistem yang akan dibuat.

2) Membangun prototyping Membangun prototyping dengan membuat perancangan sementara yang berfokus pada penyajian kepada pelanggan (misalnya dengan membuat input dan format output).

3) Evaluasi protoptyping Evaluasi ini dilakukan oleh pelanggan, apakah prototyping yang sudah dibangun sudah sesuai dengan keinginan pelanggan atau belum. Jika sudah sesuai, maka langkah selanjutnya akan diambil. Namun jika tidak, prototyping direvisi dengan mengulang langkah-langkah sebelumnya.

4) Mengkodekan sistem Dalam tahap ini prototyping yang sudah di sepakati diterjemahkan ke dalam bahasa pemrograman yang sesuai.

5) Menguji sistem Setelah sistem sudah menjadi suatu perangkat lunak yang siap pakai, kemudian dilakukan proses Pengujian. Pengujian ini dilakukan dengan White Box, Black Box, Basis Path, pengujian arsitektur, dll.

6) Evaluasi Sistem Pelanggan mengevaluasi apakah perangkat lunak yang sudah jadi sudah sesuai dengan yang diharapkan . Jika ya, maka proses akan dilanjutkan ke tahap selanjutnya, namun jika perangkat lunak yang sudah jadi tidak/belum sesuai dengan apa yang diharapkan, maka tahapan sebelumnya akan diulang.

7) Menggunakan sistem Perangkat lunak yang telah diuji dan diterima pelanggan siap untuk digunakan.[2]

\subsection{Tinjauan Pustaka}

1) Sistem Informasi Sistem menurut beberapa ahli dapat didefinisikan sebagai berikut:

- Menurut Stalling suatu sistem adalah suatu jaringan kerja dari prosedur-prosedur yang saling berhubungan, berkumpul bersama-sama untuk melakukan suatu kegiatan atau untuk menyelesaikan suatu sasaran yang tertentu.

- Dalam pengertian lain suatu sistem dapat diambil pengertian yang pada dasarnya adalah sekelompok unsur yang erat hubungannya satu dengan yang lain yang berfungsi bersama-sama untuk mencapai tujuan tertentu.

2) Koperasi Pengertian Koperasi berdasarkan UUD Nomor 25 tahun 1992 tentang Perkoperasian bahwa koperasi adalah badan usaha yang beranggotakan orang-orang atau badan hukum koperasi dengan melandaskan kegiatannya berdasarkan prinsip koperasi sekaligus sebagai gerakan ekonomi rakyat yang berdasar atas asas kekeluargaan. Pendapat lain menurut Arfinal Chaniago mengemukakan tentang perkoperasian bahwa koperasi sebagai suatu perkumpulan yang beranggotakan orangorang atau badan hukum, yang memberikan kebebasan kepada anggota untuk masuk dan keluar, dengan bekerja sama secara kekeluargaan menjalankan usaha untuk mempertinggi kesejahteraan jasmaniah para anggotanya.[7]

3) Otto Fajarianto : Metodologi dalam membangun perancangan sistem dengan menggunakan pemrograman berorientasi objek. Sedangkan untuk melakukan pengembangan sistemnya menggunakan metode prototype. Hasilnya adalah Sistem pelayanan akademik berbasis mobile ini adalah salah satu alternatif yang dapat dikembangkan oleh sebuah kampus untuk menjadi sarana penunjang pelayanan terhadap mahasiswa..[3]

4) Syahrial : Model yang digunakan untuk merancang sistem adalah dengan pemodelan terstruktur dalam bentuk DFD dan ERD yang hasilnya adalah rancangan prototype sistem informasi koperasi berbasis web pada Koperasi Unit Desa Pandan Jaya Geragai.[4]

5) Bella Hardiyana: Untuk metode pengembangan menggunakan metode terstruktur dengan beberapa alat bantu dan teknik pengerjaan seperti flowmap, diagram konteks, dan data flow diagram (DF), hasil dari penelitian ini adalah sebuah sistem informasi yang telah di uji metode pengujian black box .[5] 
6) Dwi Purnomo: Penelitian ini akan memberikan gambaran penggunaan model prototyping pada kegiatan pengembangan sistem informasi dengan menghasilkan sebuah prototype sebagai salah satu langkah awal sebuah kegiatan pengembangan sistem informasi.[6]

\section{Hasil dan Pembahasan}

Sistem berjalan yang ada pada Koperasi Pribadi manjung adalah sebuah sistem yang masih menggunakan banyak dokumen. Beberapa proses yang ada di koperasi Pribadi Manjung ngwen klaten adalah Proses pendaftaran anggota, Proses penyetoran simpanan bulanan, Proses simpanan, Proses pengajuan pinjaman, Proses pencarian pinjaman, Proses pembayaran angsuran pinjaman, Proses laporan anggota, Proses laporan simpanan anggota, Proses laporan pinjaman anggota, Proses laporan angsuran pinjaman. Analisa Sistem Berjalan Dalam proses pembuatan sistem peneliti memerlukan adanya analisis terhadap suatu sistem terlebih dahulu sebelum melakukan perancangan. Analisis sistem yang sedang berjalan merupakan salah satu langkah yang dilakukan peneliti untuk menentukan prosedur yang akan dirancang, karena dengan menganalisis sistem kita akan mengetahui kelebihan dan kekuranngan dari suatu sistem yang sedang kita teliti sehingga peneliti dapat membuat sistem yang baru.

\subsection{Analisa Sistem Berjalan}

\subsubsection{Pendaftaran Anggota Baru}

Pada gambar2. Dibawah ini menjelaskan tentang Flowmap Pendaftaran Anggota Koperasi Baru

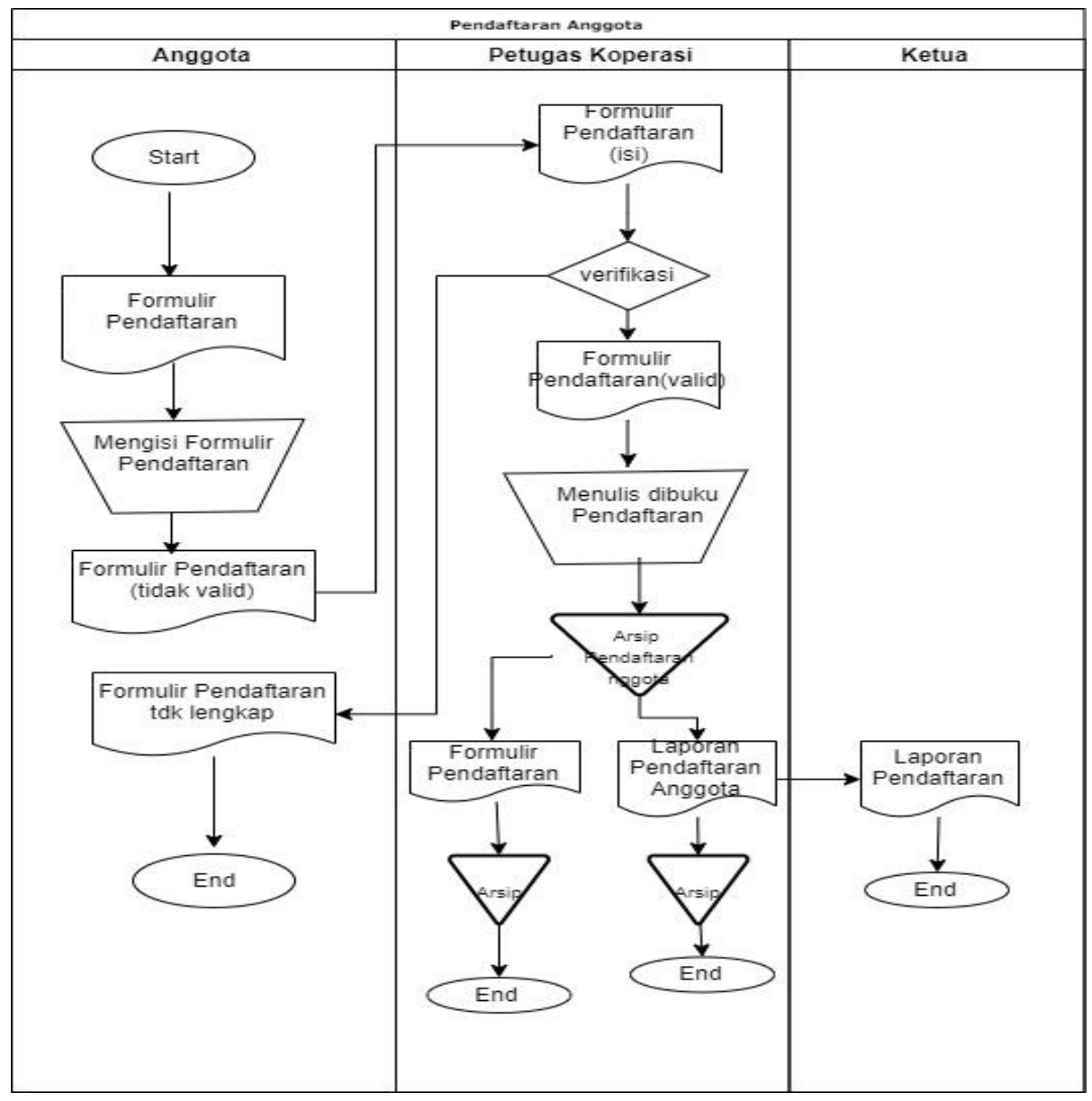

Fig. 3. Flowmap Pendaftaran Anggota Koperasi Baru 


\subsubsection{Prosedur Simpanan Anggota Baru}

Pada Fig.4 dibawah ini menjelaskan bagaimana Flowmap Prosedur Simpanan Anggota.

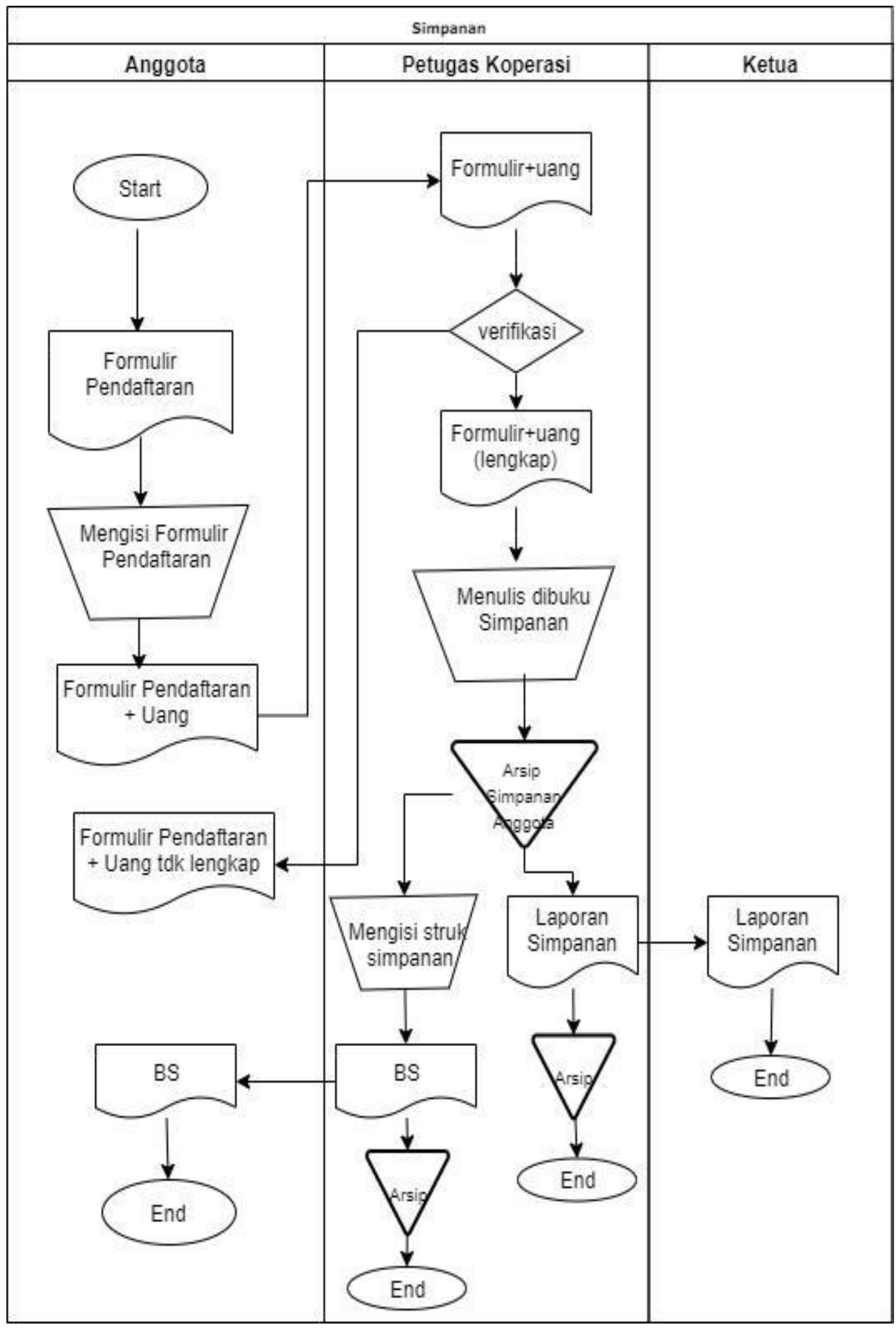

Fig.4. Flowmap Prosedur Simpanan Anggota 


\subsubsection{Prosedur Pengambilan Uang}

Sedangkan pada Fig.5 menjelaskan tentang Flowmap Pengambilan Uang, dari system.

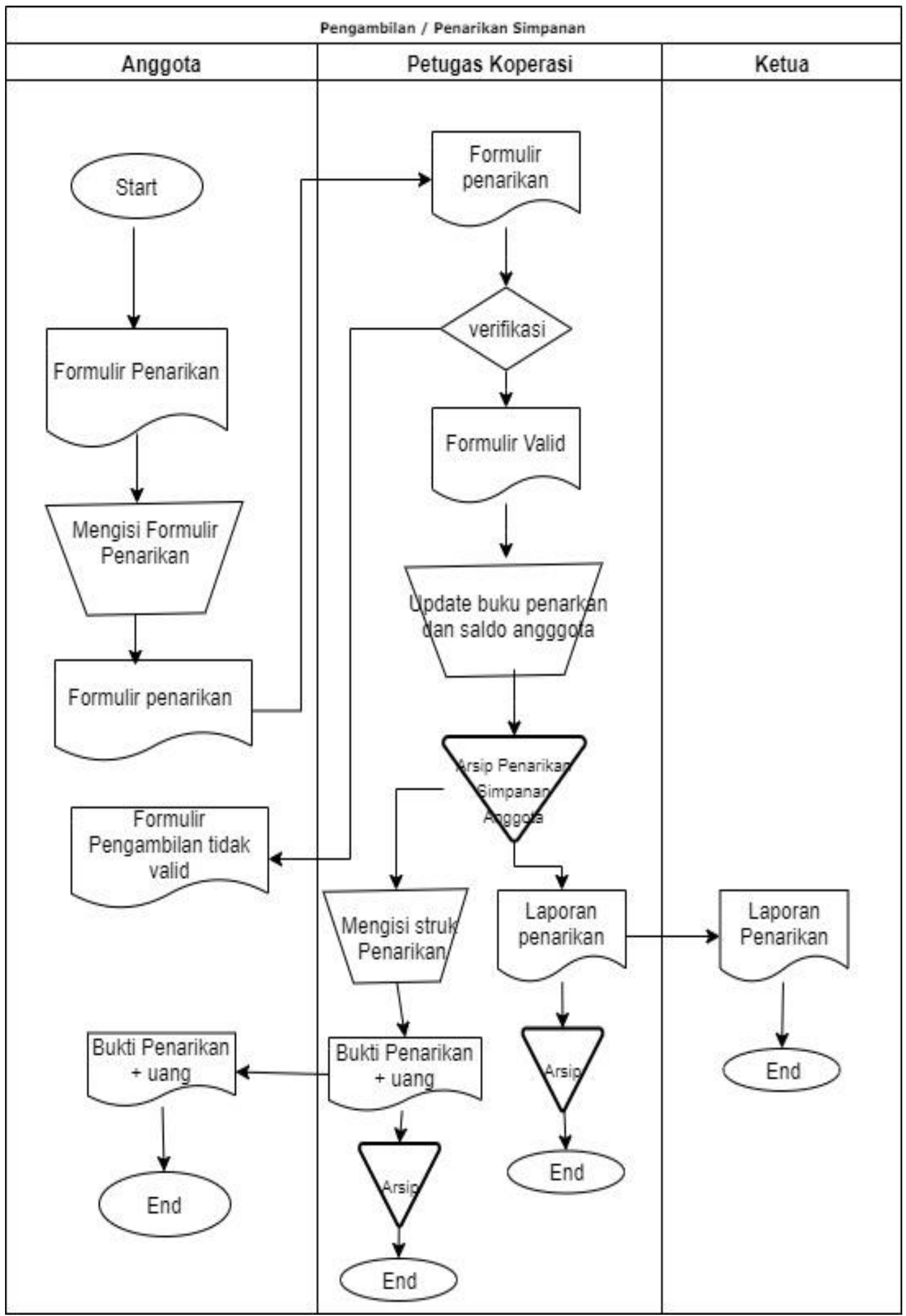

Fig.5. Flowmap Pengambilan Uang 


\subsubsection{Prosedur Pinjaman Anggota}

Pada Fig.6 menjelaskan tentang Flowmap Pinjaman Anggota

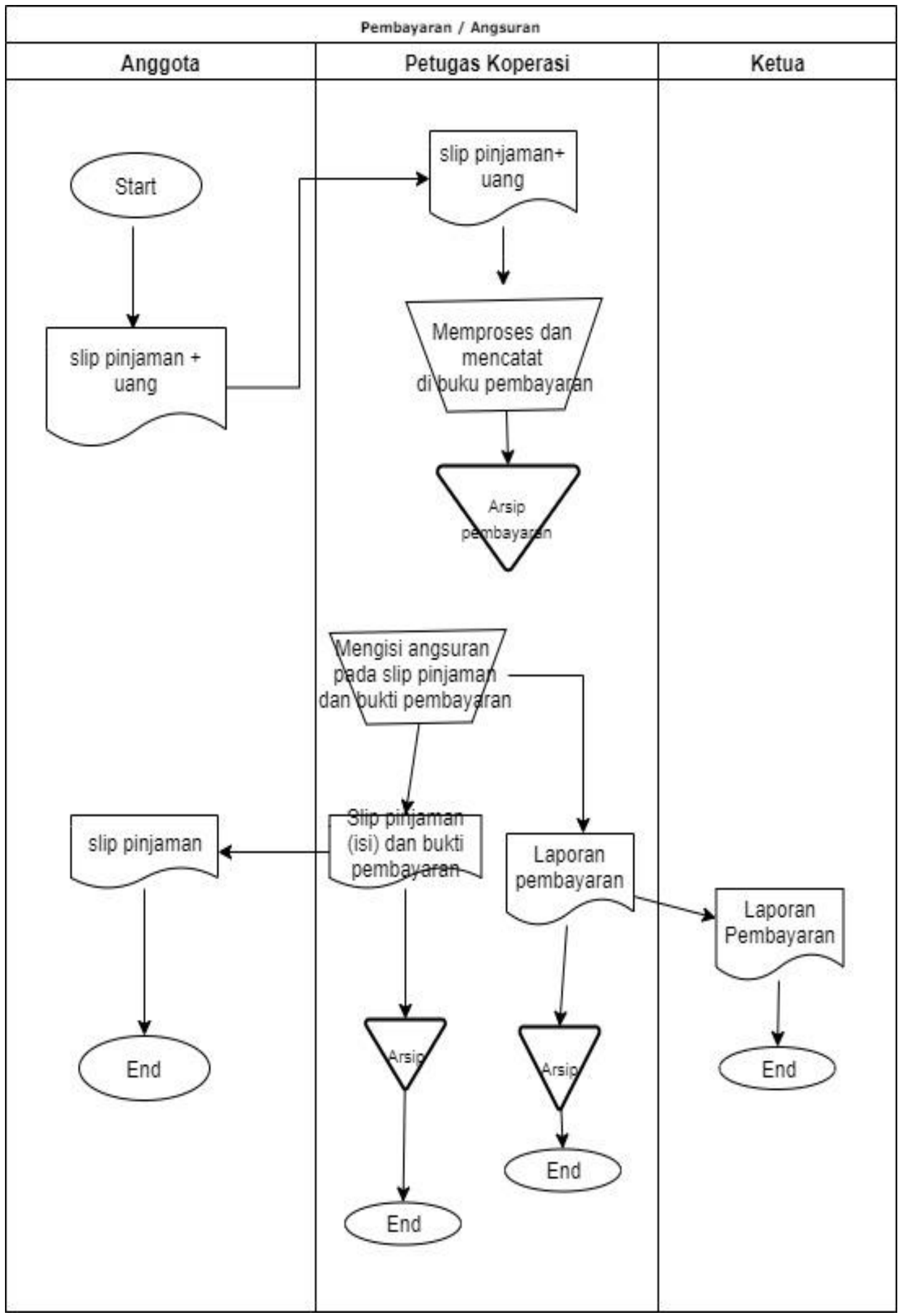

Fig.6. Flowmap Pinjaman Anggota 


\subsubsection{Prosedur Pembayaran Anggota}

Fig.7 menjelaskan tentang Flowmap Pinjaman .

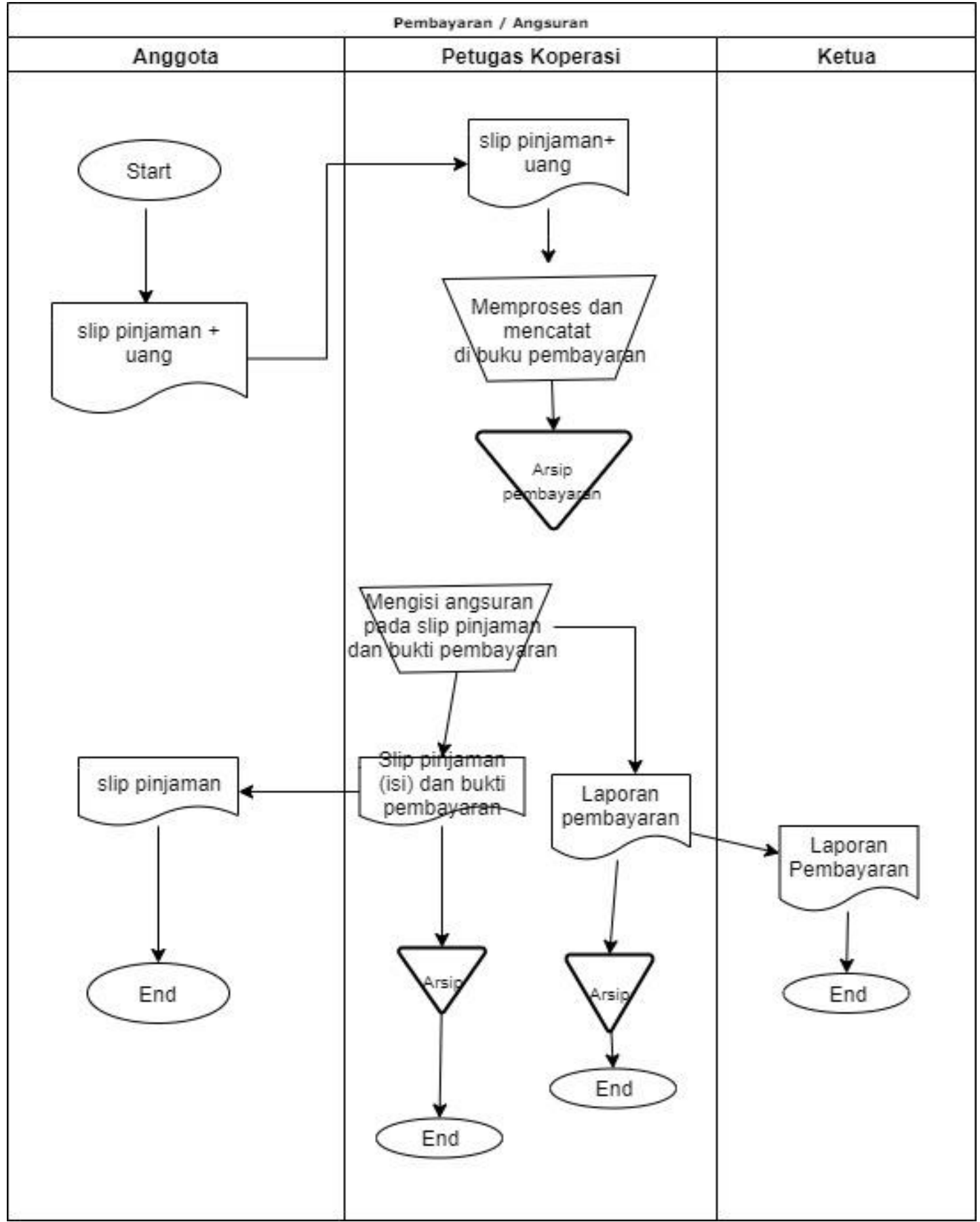

Fig.7. Flowmap Pinjaman

\subsection{Rancangan Sistem Diusulkan}

\subsubsection{Use Case Sistem Usulan}

Use Case yang diusulkan pada pengembangan system ditunjukkan pada Fig.8 dibawah ini, yang menggambarkan use case diagram sebagai berikut: 


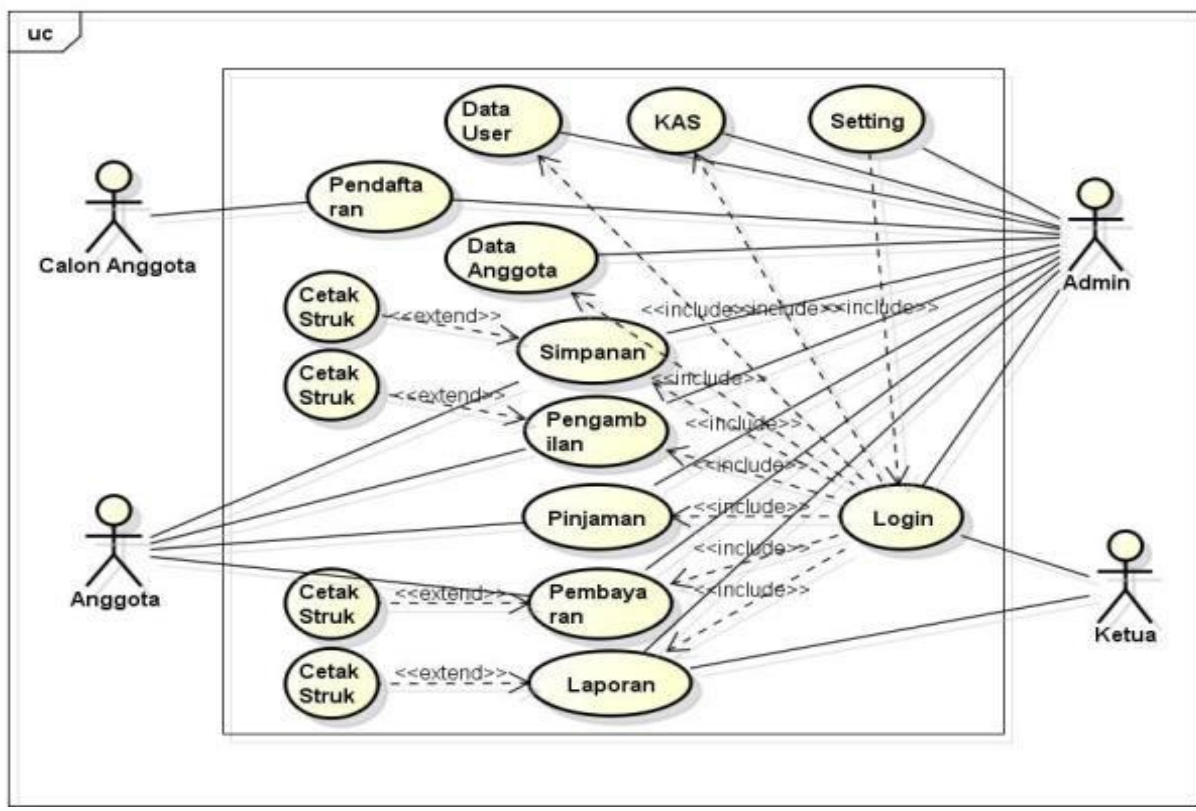

Fig.8. Use Case Diagram Sistem

\subsubsection{Activity Diagram Anggota}

Pada Fig.9 menggambarkan tentang Activity Diagram Anggota

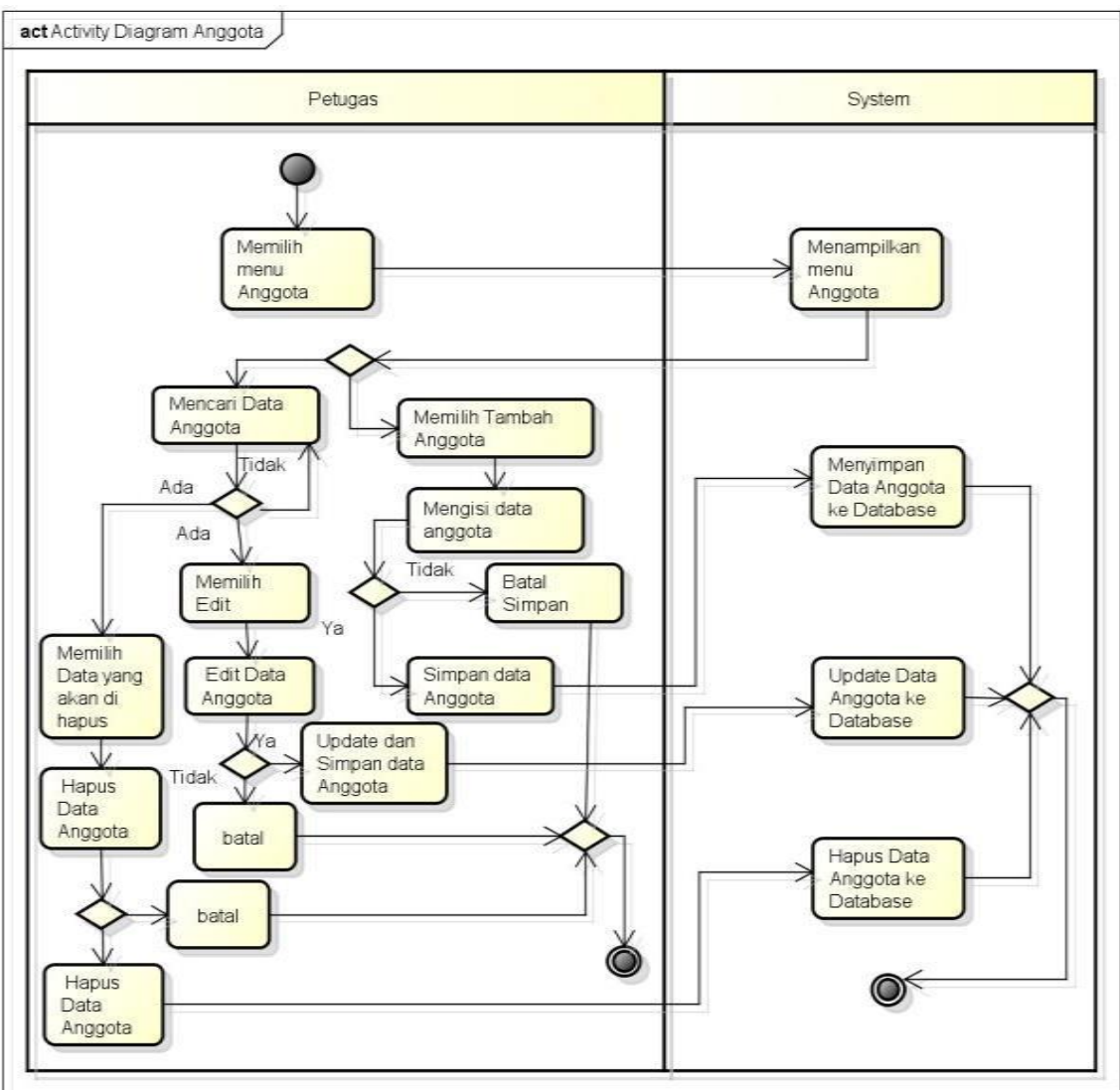

Fig.9. Activity Diagram Anggota

Maria Atik Sunarti Ekowati et.al (Pengembangan Prototype Sistem Informasi Simpan Pinjam Koperasi Pribadi Manjung Ngawen Klaten 


\subsubsection{Activity Diagram Simpanan}

Fig.10 menunjuukan Activity Diagram Simpanan dari system.

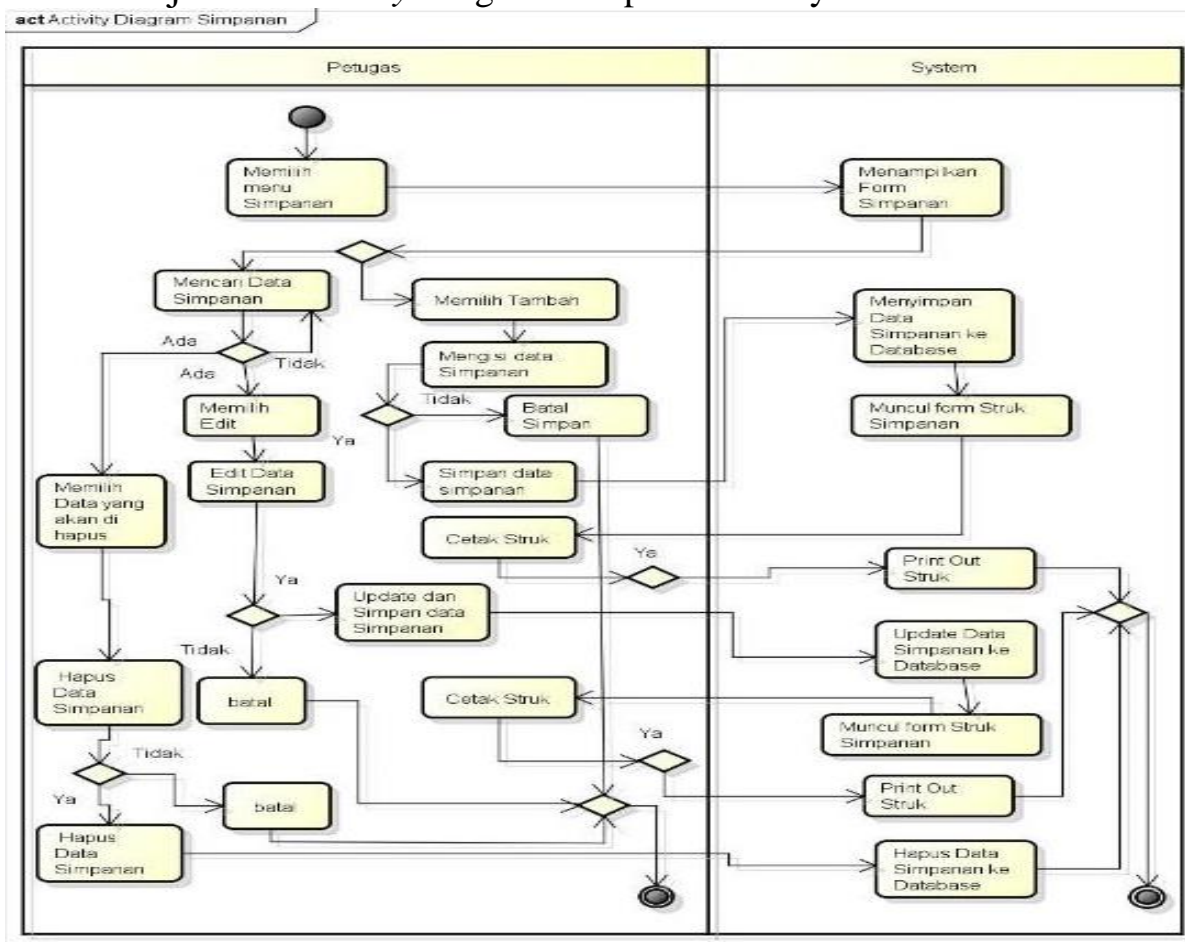

Fig.10. Activity Diagram Simpanan

\subsubsection{Activity Diagram Pengambilan}

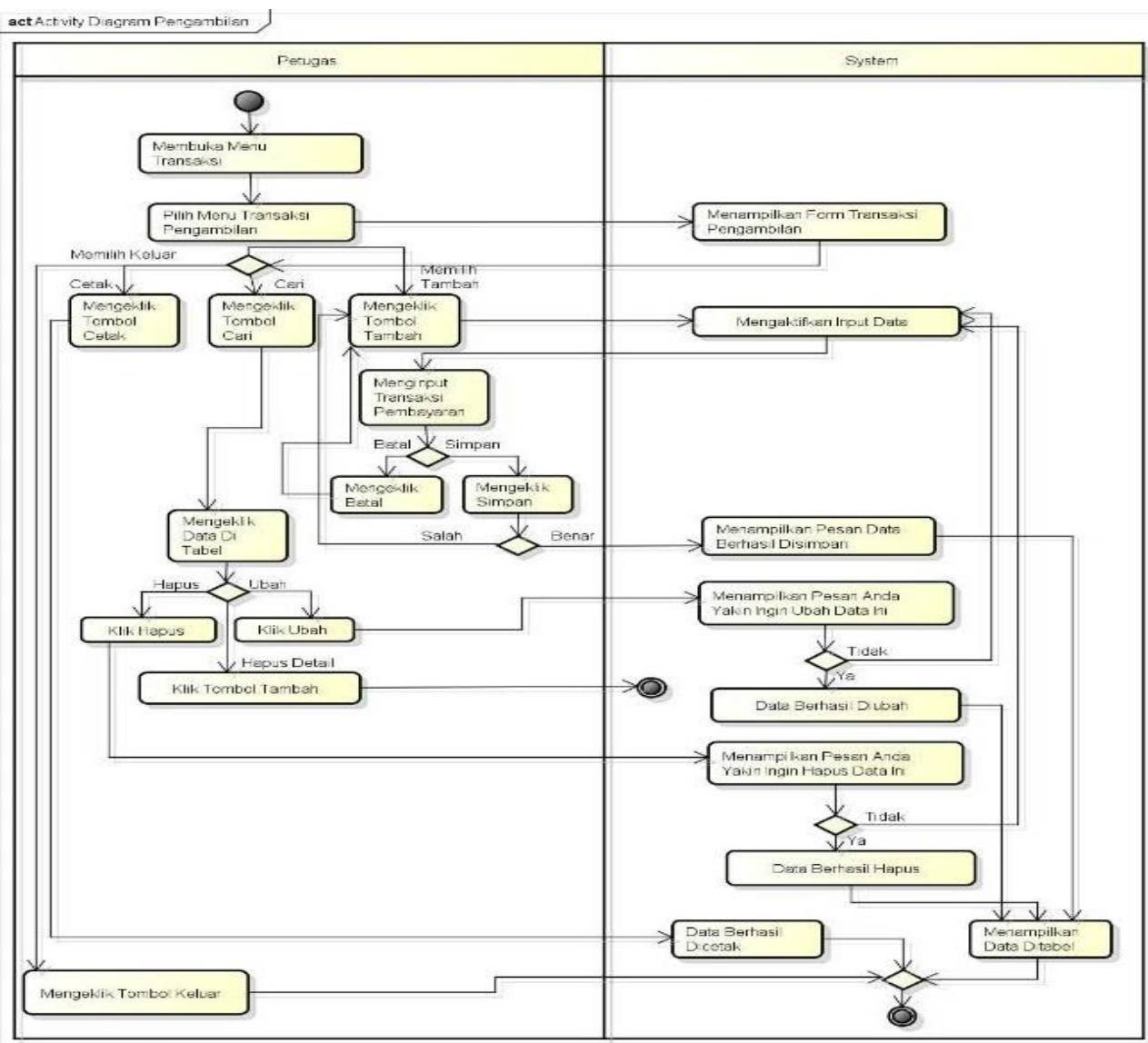

Fig.11. Activity Diagram Pengambilan

Maria Atik Sunarti Ekowati et.al (Pengembangan Prototype Sistem Informasi Simpan Pinjam Koperasi Pribadi Manjung Ngawen Klaten) 


\subsubsection{Acitivity Diagram Pinjaman}

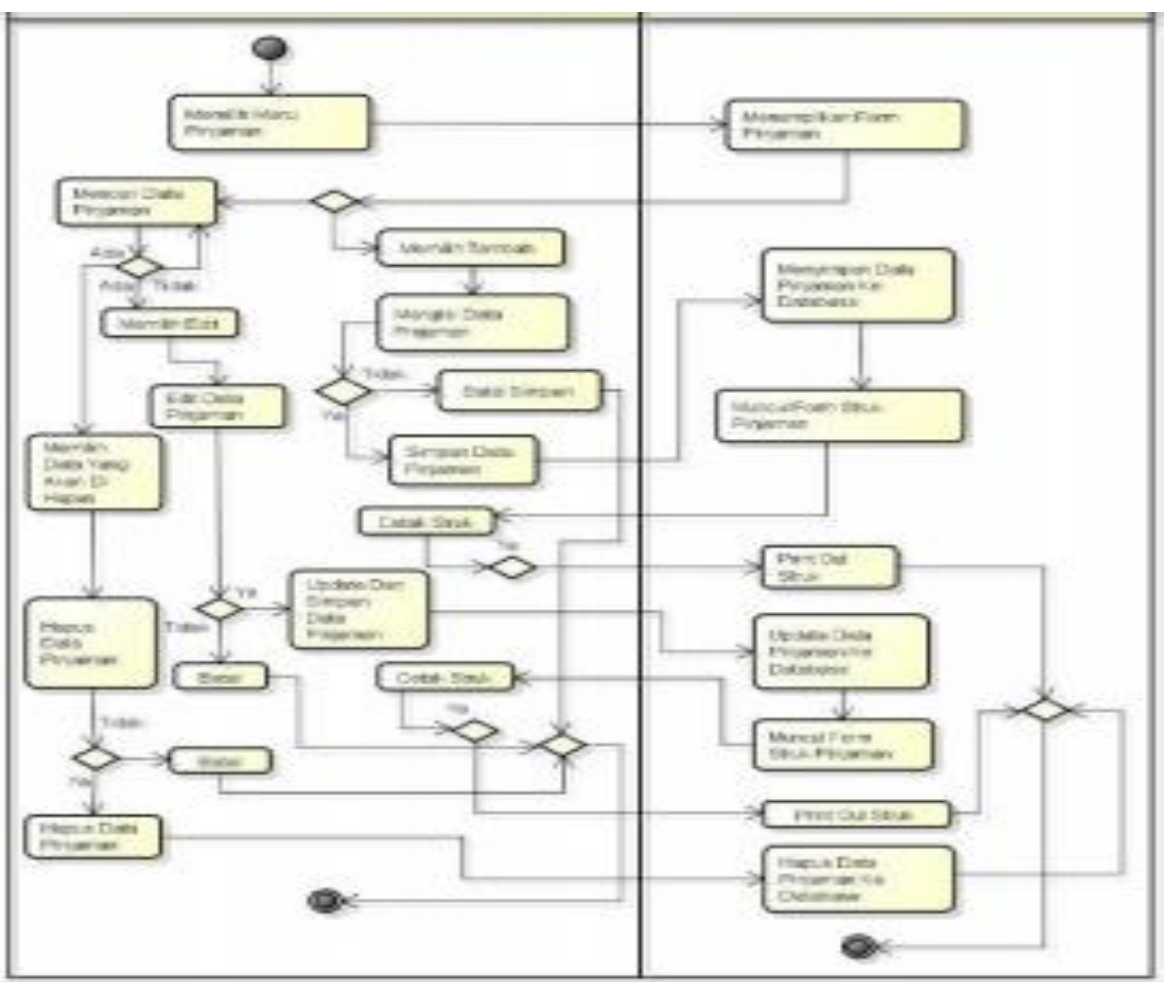

Fig.12. Activity Diagram Pinjaman

\subsubsection{Activity Diagram Pembayaran}

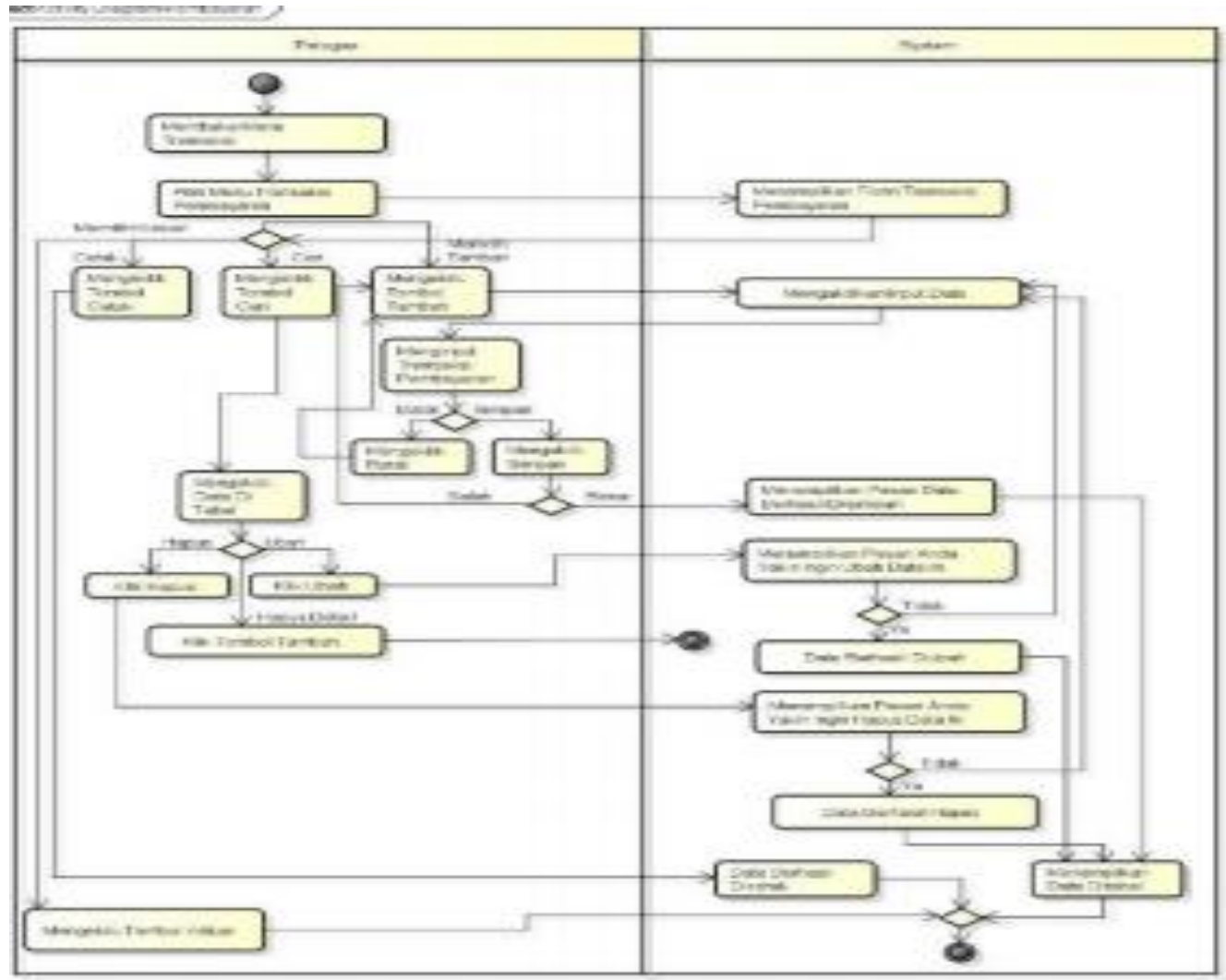

Fig.13. Activity Diagram Pembayaran

Maria Atik Sunarti Ekowati et.al (Pengembangan Prototype Sistem Informasi Simpan Pinjam Koperasi Pribadi Manjung Ngawen Klaten 


\subsection{Class Diagram}

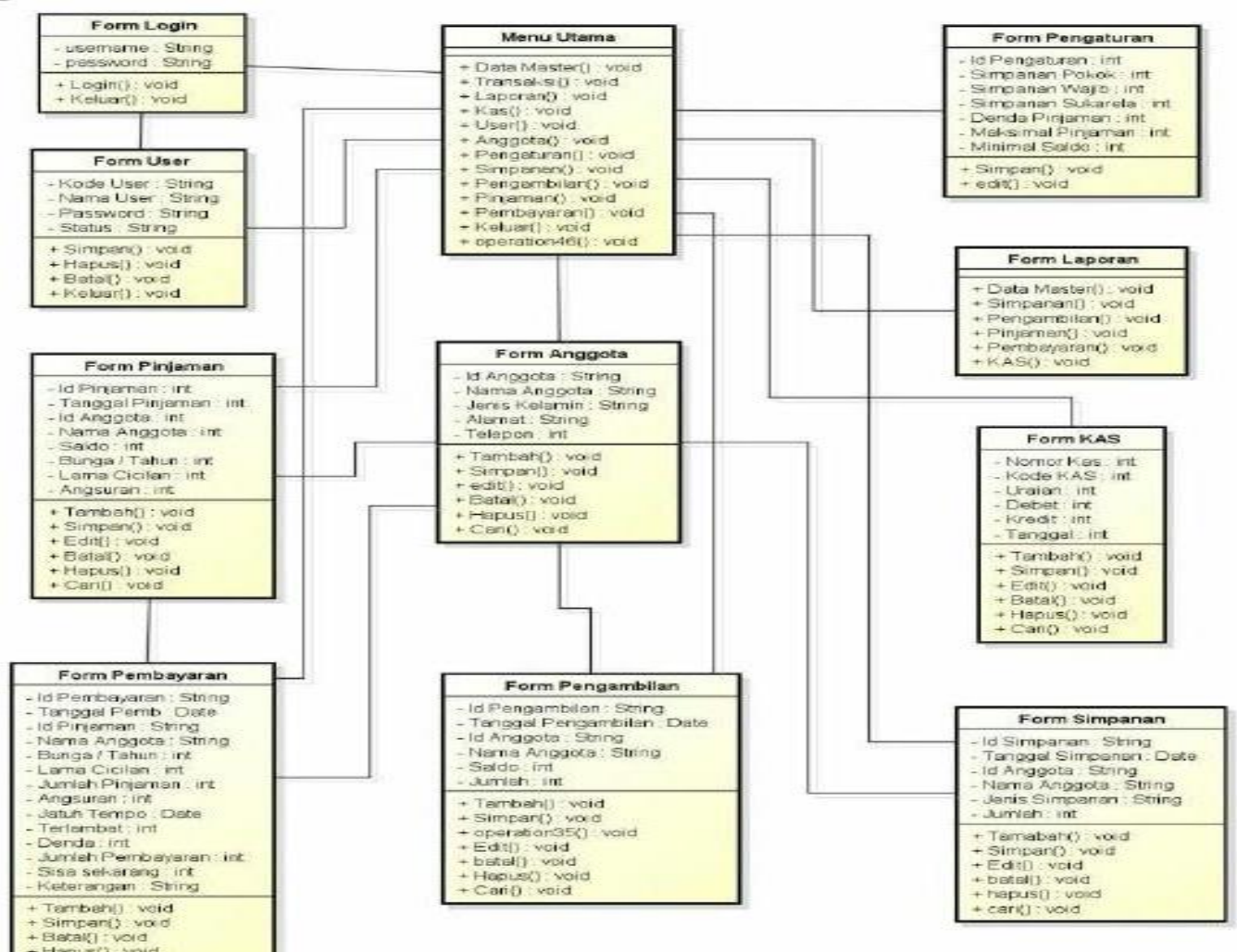

Fig.14. Class Diagram

\section{HASIL DAN PEMBAHASAN}

\subsection{Tampilan Output Program}

\subsubsection{Menu Anggota}

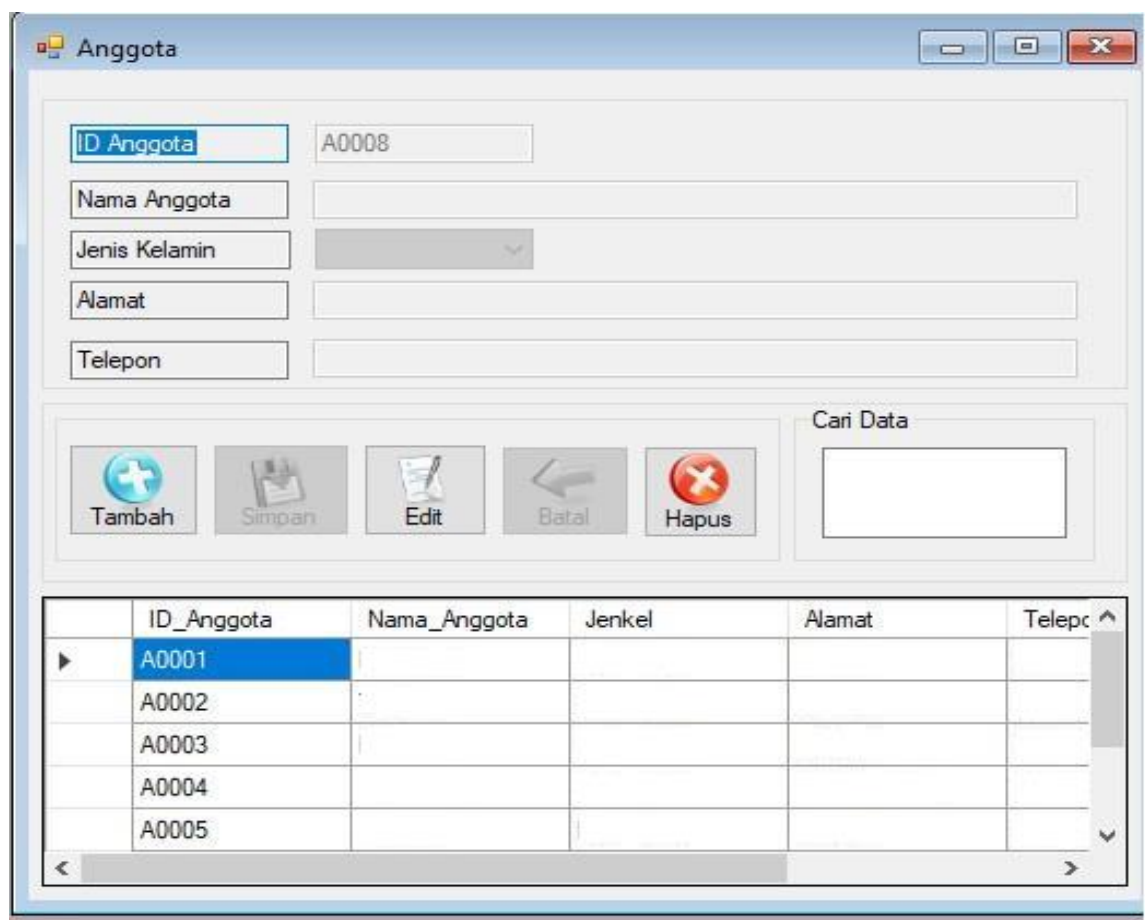

Fig.15. Tampilan Menu Anggota 


\subsubsection{Screen Shot Menu Simpanan}

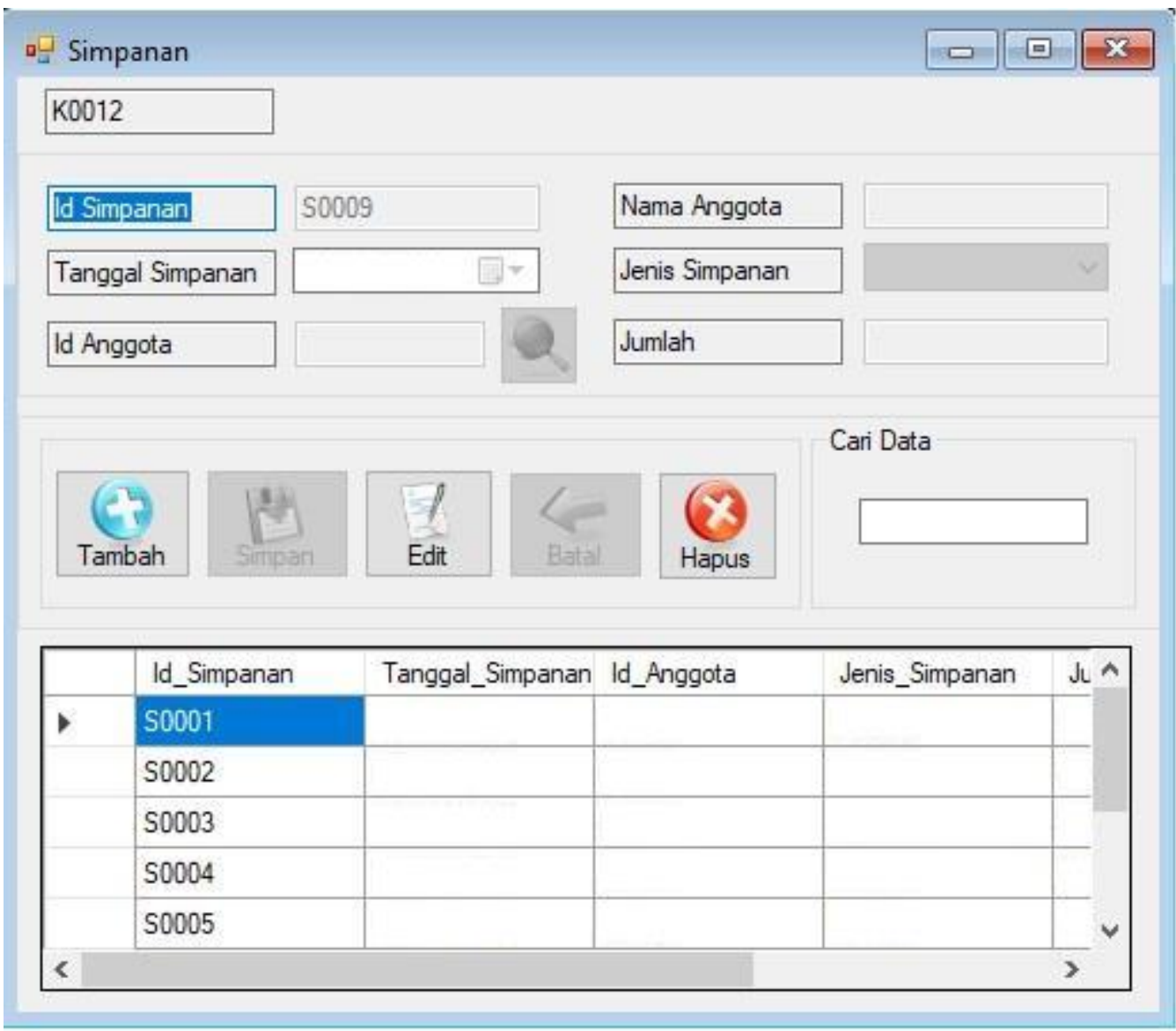

Fig.16. Menu Simpanan

\subsubsection{Menu Pengambilan}

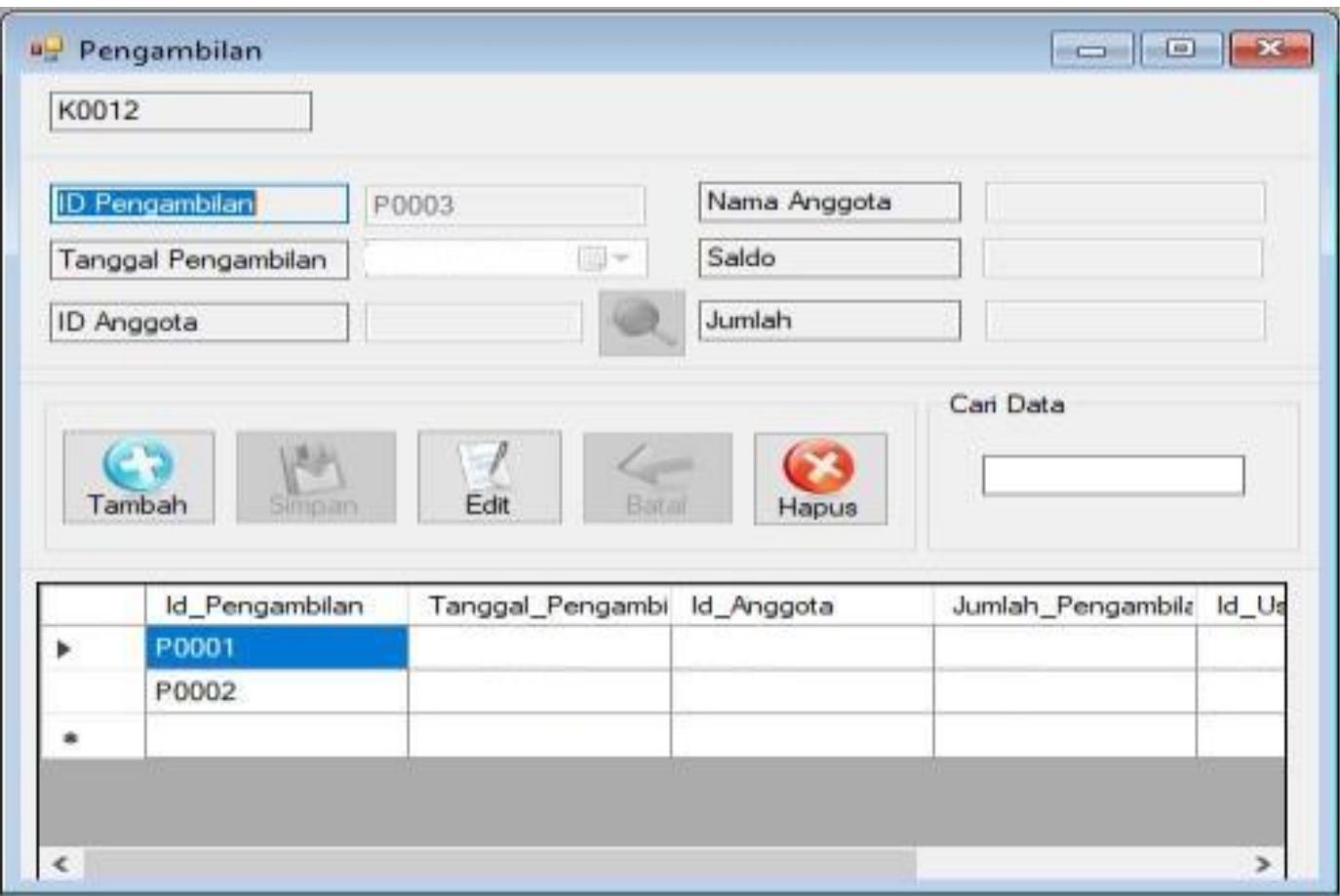

Fig.17. Menu pengambilan 


\subsubsection{Menu Pinjaman}

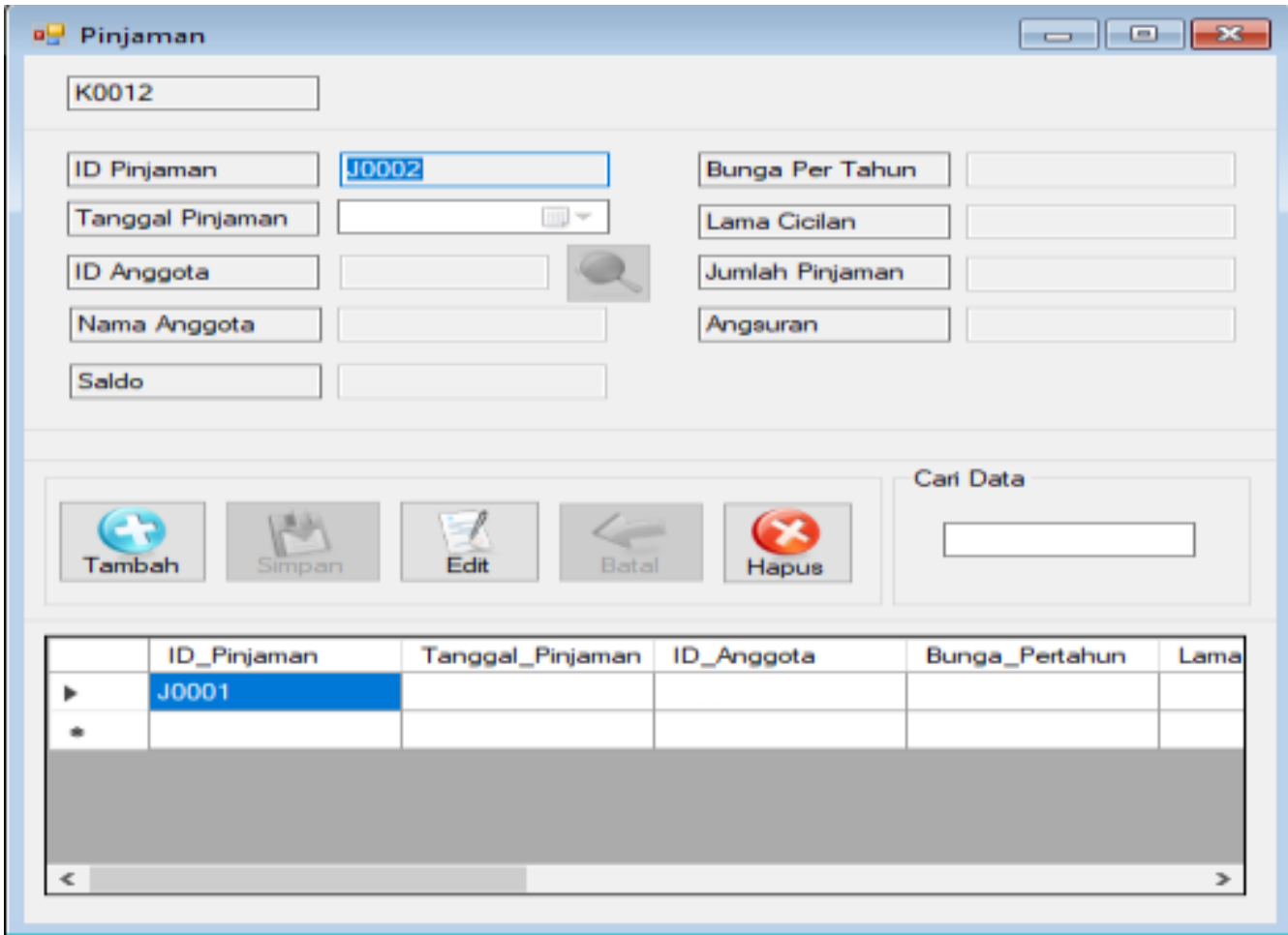

Fig.18. Menu Pembayaran

\section{KESIMPULAN DAN SARAN}

\subsection{Kesimpulan}

1. Dari hasil implementasi Sistem informasi simpan pinjam pada koperasi PRIBADI dikembangkan dharapkan dapat mengelola data simpanan, data pinjaman dan data angsuran guna membantu peningkatan kinerja pelayanan yang baik pada anggota.

2. Terdapat menu pencetakan, laporan yang diperlukan sudah dapat dicetak artinya memudahkan dan mempercepat dalam mengambil keputusan

3. Meringankan pekerjaan pengarsipan dan pengolahan data yang masuk menjadi lebih cepat dan akurat.

\section{DAFTAR PUSTAKA}

[1] Karman, J., \& Martadinata, A. T. (2017). Sistem Informasi Geografis Lokasi Pemetaan Masjid Berbasis Android Pada Kota Lubuklinggau. Stmik Musirawas.

[2] MADCOMS. (2016). PEMROGRAMAN PHP dan MySQL untuk pemula. In ANDI.

[3] Nugroho, B. (2014). Dasar Pemrograman Web PHP-MySQL dengan Dreamweaver. Gava Media. https://doi.org/10.1016/0378-1119(87)90155-7

[4] Pratiwi, P., \& Herliana, A. (2016). ANALISIS DAN DESAIN SISTEM INFORMASI SIMPAN PINJAM PADA KOPERASI SEJAHTERA BERSAMA BANDUNG. Jurnal Informatika. https://doi.org/10.31311/ji.v2i1.71

[5] Subhan, M. (2012). Analisa PErancangan Sistem. In Analisa perancangan sistem.

[6] Sutabri, T. (2012). Analisis Sistem Informasi. In Analisa Sistem Informasi.

[7] Wahana, K. (2015). Membangun Sistem Informasi Java dengan NetBeans dan MySQL. Andi Ofset. 